Check for updates

The BMJ

fgodlee@bmj.com Follow Fiona on Twitter @fgodlee

Cite this as: BMJ2020;371:m4161 http://dx.doi.org/10.1136/bmj.m4161 Published: 29 October 2020

\title{
Covid-19: Why we still need more women in academia
}

\section{Fiona Godlee editor in chief}

One small but significant impact of the covid pandemic has been its constraining effect on the academic output of women. The first signs of a sex imbalance were seen in the overwhelmingly male line-ups of experts speaking about covid-19 and the poor representation of women on government pandemic advisory panels. ${ }^{12}$ Meanwhile journals, including The BMJ and our specialty journals, have seen a worrying drop in the proportion of female first authors of research papers. It seems that, while lockdown may have provided men with time and space to boost their academic output, school closures have hit many women with a disproportionate burden of childcare.

This shows the fragility of any advances to sex equality in academia and the importance of structures that support and incentivise progress. All the more reason to mourn another casualty of the pandemic: the tie-up between funding from the UK's National Institutes of Health Research (NIHR) and advances in sex equality. ${ }^{3}$ Since its inception in 2011 the Athena SWAN initiative has had a substantial effect on the proportion of grants going to female researchers and their teams, say Pavel Ovseiko and colleagues.

Because of the way women tend to operate, this has meant research that is more multidisciplinary, rigorous, relevant, and honest. ${ }^{4}$

Sadly, there is no guarantee that these positive trends will be sustained now that the NIHR's incentives have been dropped, says Sarah Stewart-Brown, ${ }^{5}$ and there is a mountain to climb before women achieve anything like equality in academia's top leadership positions.

Could male predominance explain some of the intense heat of the current debates about covid-19? Perhaps so, if an excess of certainty can be considered a male characteristic. To redress this imbalance, three men this week call for the uncertainties surrounding the pandemic to be more openly acknowledged. "When deciding whom to listen to in the covid-19 era, we should respect those who respect uncertainty, and listen in particular to those who acknowledge conflicting evidence on even their most strongly held views," say George Davey Smith and colleagues. ${ }^{6}$

To help people face up to the "known unknowns" of the pandemic, The BMJ has joined forces with these authors in hosting a one day international meeting on 20 November. You can register at bmj.com. Do also join us for our weekly podcast conversations about covid, in which The BMJ's regular contributors ask a guest expert for their views on the second wave (https://soundcloud.com/bmjpodcasts/sets/the-bmjpodcast). This week we achieve the perfect sex balance, with two excellent women and two excellent men.
1 Chatfield C, Hurley R, Ladher N, Loder E, Richards R, Schroter S. Where are the women experts on covid-19? Mostly missing. BMJ Opinion. 25 Jun 2020. https://blogs.bmj.com/bmj/2020/06/25/where-are-the-women-expertson-covid-19-mostly-missing.

2 Wenham C, Smith J, Morgan R. Covid-19 is an opportunity for gender equality within the workplace and at home. BMJ Opinion. 15 Apr 2020 https://blogs.bmj.com/bmj/2020/04/15/covid-19-is-an-opportunity-forgender-equality-within-the-workplace-and-at-home.

3 Seven days in medicine: 23-29 September 2020. BMJ 2020;371:m3770.pmid: 33004414

4 Ovseiko PV, Taylor M, Gilligan RE, etal. Effect of Athena SWAN funding incentives on women's research leadership. BMJ2020;371:m3975. doi: 10.1136/bmj.m3975 pmid: 33106283

5 Stewart-Brown S. Gender diversity in academic medicine. BM 2020;371:m4076. doi: 10.1136/bmj.m4076 pmid: 33106233

6 Davey Smith G, Blastland M, Munafò M. Covid-19's known unknowns. BMJ 2020;371:m3979. doi: 10.1136/bmj.m3979 pmid: 33077431

This article is made freely available for use in accordance with BMJ's website terms and conditions for the duration of the covid-19 pandemic or until otherwise determined by BMJ. You may use, download and print the article for any lawful, non-commercial purpose (including text and data mining) provided that all copyright notices and trade marks are retained. 